University of Rhode Island

DigitalCommons@URI

Past Departments Faculty Publications (CELS) College of the Environment and Life Sciences

1990

\title{
CALCIUM UTILIZATION IN CONTRACTURES INDUCED BY ACETYLCHOLINE OR HIGH-POTASSIUM SALINE IN MOLLUSCAN PROBOSCIS MUSCLES
}

\author{
D. D. Brooks \\ University of Rhode Island \\ H. Huddart \\ University of Rhode Island \\ R. Lennard \\ University of Rhode Island \\ R. B. Hill \\ University of Rhode Island
}

Follow this and additional works at: https://digitalcommons.uri.edu/cels_past_depts_facpubs

Terms of Use

All rights reserved under copyright.

Citation/Publisher Attribution

Brooks, D. D., Huddart, H., Lennard, R., \& Hill, R. B. (1990). CALCIUM UTILIZATION IN CONTRACTURES INDUCED BY ACETYLCHOLINE OR HIGH-POTASSIUM SALINE IN MOLLUSCAN PROBOSCIS MUSCLES. Journal of Experimental Biology, 149(1), 379-394. Retrieved from http://jeb.biologists.org/content/149/1/ 379.

Available at: http://jeb.biologists.org/content/149/1/379

This Article is brought to you for free and open access by the College of the Environment and Life Sciences at DigitalCommons@URI. It has been accepted for inclusion in Past Departments Faculty Publications (CELS) by an authorized administrator of DigitalCommons@URI. For more information, please contact digitalcommonsgroup@uri.edu. 


\title{
CALCIUM UTILIZATION IN CONTRACTURES INDUCED BY ACETYLCHOLINE OR HIGH-POTASSIUM SALINE IN MOLLUSCAN PROBOSCIS MUSCLES
}

\author{
BY D. D. BROOKS*, H. HUDDART $\dagger$, R. LENNARD* AND R. B. HILL \\ Department of Zoology, The University of Rhode Island, \\ Biological Sciences Center, Kingston, Rhode Island 02881, USA
}

Accepted 12 November 1989

\begin{abstract}
Summary
The mechanisms by which high- $\mathrm{K}^{+}$saline and acetylcholine (ACh) mobilize cellular calcium in molluscan muscle was studied in three proboscis muscles of Busycon canaliculatum. BAY K 8644, a calcium agonist, enhanced tonic force induced by exposure to $25 \mathrm{mmol}^{-1} \mathrm{~K}^{+}$in the odontophore and radular retractor muscles but inhibited this response in the radular sac muscle. Its effect on the radular protractor muscle was concentration-dependent, excitatory at $10^{-7} \mathrm{moll}^{-1}$ and inhibitory at higher concentrations. The tonic response to $80 \mathrm{mmol}^{-1} \mathrm{~K}^{+}$was enhanced by BAY K 8644 in the odontophore retractor and radular retractor muscles but inhibited in the radular sac muscle. In all muscles, BAY K 8644 eliminated the fast twitches induced by $80 \mathrm{mmoll}^{-1} \mathrm{~K}^{+}$, and inhibited the tonic ACh responses. Sucrose-gap studies with the radular protractor muscle showed that the effects of BAY K 8644 on the depolarizations induced by $\mathrm{K}^{+}$and $\mathrm{ACh}$ were similar. The effect on the ACh-induced depolarization suggested that this agent had inhibited sodium influx through the $\mathrm{ACh}$ receptor.

Mytelase enhanced ACh-induced tonic force, but at $10^{-4} \mathrm{~mol}^{-1}$ it inhibited the response to doses of $\mathrm{ACh}$ above $10^{-5} \mathrm{moll}^{-1}$. Mytolon reduced the maximum $\mathrm{ACh}$-induced tonic force and increased the response threshold to $\mathrm{ACh}$. $\mathrm{ACh}$ and high- $\mathrm{K}^{+}$depolarization pathways were not synergistic for force development.

The existence of two separate cellular calcium pools, independently released by high- $\mathrm{K}^{+}$saline and $\mathrm{ACh}$, seems improbable. We suggest that $\mathrm{K}^{+}$and $\mathrm{ACh}$ act via separate mechanisms to release calcium from a single cellular calcium pool.
\end{abstract}

\section{Introduction}

The proboscis muscles of Busycon canaliculatum require extracellular calcium UK.

* Permanent address: School of Applied Biology, Lancashire Polytechnic, Preston PR1 2TQ,

$\dagger$ Permanent address: Division of Biological Sciences, Institute of Environmental and Biological Sciences, University of Lancaster, Lancaster LA1 4YQ, UK.

Key words: Buyscon canaliculatum, proboscis muscles, BAY K $8644, \mathrm{~K}^{+}$and $\mathrm{ACh}$ responses, Rellular calcium. 
for contraction (Huddart et al. 1990 b). A recent study of three of these muscles, the odontophore retractor, radular retractor and radular sac muscle, has revealed a great diversity in their responses to exposure to potassium or acetylcholine (Huddart et al. 1990a). These muscles all showed large differences in the way in which they responded to some commonly employed calcium antagonist drugs of mammalian smooth muscle (Huddart et al. 1990b). The antagonists studied, diltiazem, nifedipine and verapamil, had little effect upon sustained tonic force induced by exposure to high- $\mathrm{K}^{+}$saline but they appeared to enhance fast twitch activity induced by low- $\mathrm{K}^{+}$saline. They had differential effects on $\mathrm{ACh}$-induced activity and $\mathrm{K}^{+}$-induced activity in these muscles. All three antagonists reduced or eliminated $\mathrm{ACh}$-induced tonic contractures but two, verapamil and nifedipine, like serotonin (Hill, 1958), induced fast twitches in the responses to ACh (Huddart et al. 1990b).

The ACh response of Busycon proboscis muscles is normally a smooth maintained tonic contracture without twitch activity (Hill et al. 1970; Hill and McDonald-Ordzie, 1979; Hill and Licis, 1981, 1985; Huddart and Hill, 1988; Huddart et al. 1990a). These previous studies suggest that $\mathrm{K}^{+}$-induced and $\mathrm{ACh}$ induced depolarization of these muscles act through quite separate membrane transduction routes upon the cellular stores of calcium required for contraction. This might explain why the responses of some molluscan muscles to inorganic calcium antagonists such as manganese and calcium-free media (Reilly and Peretz, 1987) are different from the responses to the organic calcium antagonists used in our recent experiments.

A more radical explanation of the differences in reaction of $\mathrm{ACh}$ and $\mathrm{K}^{+}$in molluscan muscle to these agents has been proposed which envisages that $\mathrm{ACh}$ and $\mathrm{K}^{+}$may act to release calcium from two separate independent cellular calcium stores (Bloomquist and Curtis, 1975; Sugi and Yamaguchi, 1976; Reilly and Peretz, 1987). If this were so, it would explain why the responses of molluscan muscle to $\mathrm{K}^{+}$and $\mathrm{ACh}$ are so different in the presence of agents modulating calcium movement across the muscle fibre membrane.

Here we have attempted to differentiate between $\mathrm{K}^{+}$-induced calcium influx and $\mathrm{ACh}$-induced sodium influx as induction mechanisms for the release of cellular calcium. We have used the calcium agonist BAY K 8644, the anti-cholinesterase Mytelase and the anti-cholinergic Mytolon to differentiate between the two cellular calcium access pathways in $\mathrm{ACh} / \mathrm{K}^{+}$synergism studies. Our results do not support the view that $\mathrm{ACh}$ - and high- $\mathrm{K}^{+}$-induced depolarization gain access to independently modulated cellular calcium pools. Instead, they suggest that in these muscles high- $\mathrm{K}^{+}$saline and $\mathrm{ACh}$ may act via separate transduction mechanisms upon a single cellular calcium pool.

\section{Materials and methods}

Mature Busycon canaliculatum, weighing 250-350 g, were obtained from Wood 
Hole Marine Biological Laboratory and kept in aerated sea water at $16^{\circ} \mathrm{C}$. The radular protractor, the radular retractor, the odontophore retractor and the radular sac muscle were dissected from the proboscis. The location and activity of these muscles have been described elsewhere (Huddart et al. 1990a). The muscles were placed in aerated sea water, and ligated at their insertions with fine monofilament nylon. They were then suspended in glass-jacketed organ baths between a glass hook and the force plate of Grass FT.03 force-displacement transducers. A passive load of $1 \mathrm{~g}$ was applied to the radular retractor muscles and a load of $0.5 \mathrm{~g}$ was applied to the other muscles. The transducer outputs were connected to four-channel Grass model 7 polygraphs to display tension developed. The organ baths were cooled to $14^{\circ} \mathrm{C}$ with a closed-circuit cooler/circulator system and the bath contents were constantly aerated.

High- $\mathrm{K}^{+}$depolarization of the muscles was achieved by direct addition of appropriate amounts of $3 \mathrm{moll}^{-1} \mathrm{KCl}$ stock solution. Responses obtained in this way do not differ from those obtained with equimolar $\mathrm{K}^{+} / \mathrm{Na}^{+}$substitution (Huddart and Hill, 1988). Acetylcholine was applied to the preparations by direct addition to the baths of $10 \mathrm{mmoll}^{-1}$ stock solution made up in sea water. After setting up, the preparations were allowed to equilibrate for $30 \mathrm{~min}$ and a standard time interval of $20 \mathrm{~min}$ was allowed between high- $\mathrm{K}^{+}$and $\mathrm{ACh}$ exposures.

The calcium agonist BAY K 8644, a gift from Bayer Pharmaceuticals, was made up as a $25 \mathrm{mmol}^{-1}$ stock solution in ethanol. The final ethanol level did not exceed $0.1 \%$, which has no effect on the preparations (Huddart and Hill, 1988). Experiments with BAY K 8644 were carried out in low lighting because of the photosensitivity of this compound. The anti-cholinesterase Mytelase (ambenonium chloride) and the cholinoreceptor antagonist Mytolon (benzoquinonium chloride) were gifts from the Sterling-Winthrop Research Institute and were made up as $10 \mathrm{mmol} \mathrm{l}^{-1}$ stock solutions in sea water.

The electrophysiological effects of BAY K 8644 were recorded using a single sucrose-gap system described previously (Hill and Licis, 1985; Huddart and Hill, 1988). Briefly, the muscles were drawn through fine holes in the sucrose compartment rubber membranes and their ligatures attached to right and left tension transducers. Compound membrane potential differences between the two lateral compartments were monitored with IVM silver/silver chloride flat-tipped probes and displayed, along with the force transducer outputs, on a Grass model 7 polygraph. Through the central compartment flowed $0.75 \mathrm{moll}^{-1}$ sucrose, with sea water flowing through the lateral compartments. Each experiment was begun with a depolarization of the reference (right) end of the muscle using isotonic $0.56 \mathrm{moll}^{-1} \mathrm{KCl}$. This side of the muscle was kept depolarized throughout the experiment. The membrane potential difference between right and left compartments represented the compound resting potential of the left end of the muscle, which was usually maximal within 3-6 min of depolarization. Drugs and test agents in sea water were introduced to the left (test) compartment and the resulting membrane potential changes and tension developed were recorded qimultaneously. 


\section{Results \\ The effects of BAY K 8644}

BAY K 8644 is a dihydropyridine which is a very effective slow calcium channel agonist in several mammalian smooth muscles (Kanmura et al. 1984; Finet et al. 1985; Gopalakrishnan et al. 1985; Mikkelsen, 1985), although Langton and Huddart (1988) found that it also enhanced fast twitch activity in rat prostatic vas deferens, an activity thought to depend upon fast voltage-sensitive calcium channels.

BAY K 8644 had different effects on the different muscles. In the odontophore and radular retractor muscle, it enhanced tonic force in response to $25 \mathrm{mmoll}^{-1}$ $\mathrm{K}^{+}$without chronotropic effect on fast twitch activity, and recovery took about $2 \mathrm{~h}$ (Fig. 1A,B). In the radular sac muscle, BAY K 8644 caused slight inhibition of the tonic force in response to $25 \mathrm{mmol}^{-1} \mathrm{~K}^{+}$. At the highest concentration used
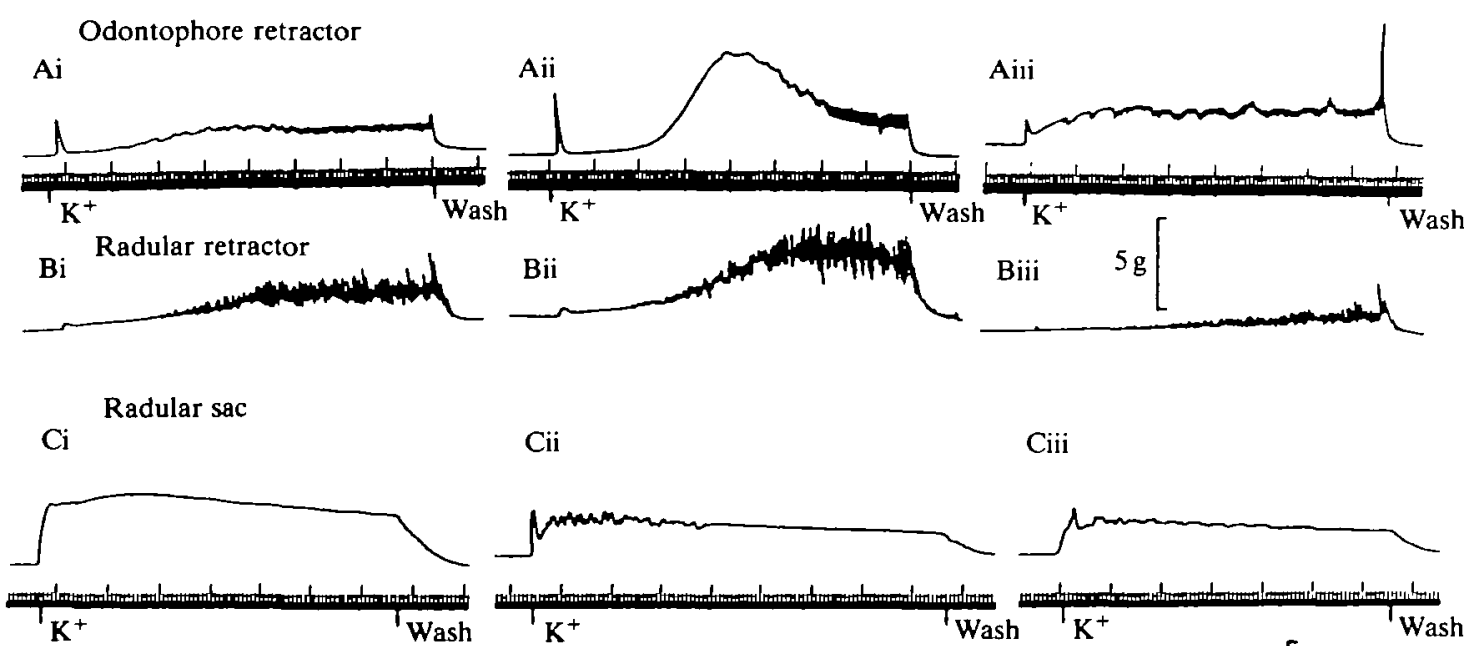

Cii Ciii

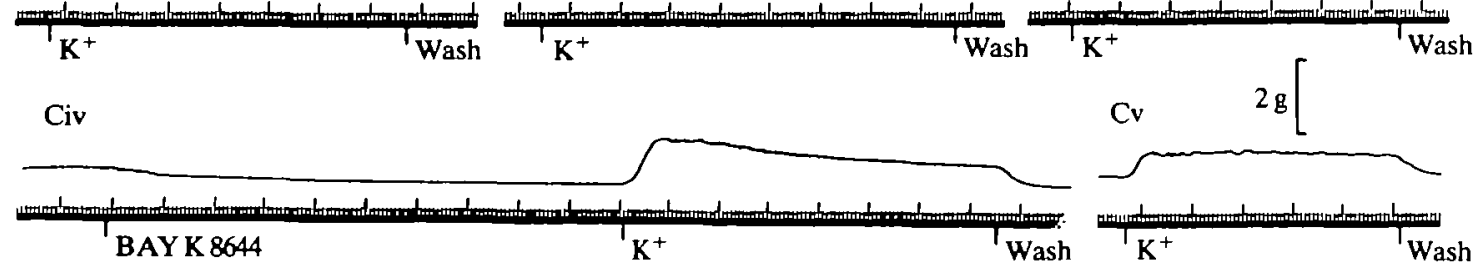

Fig. 1. The effect of BAYK 8644 on activity induced by $25 \mathrm{mmol}^{-1} \mathrm{~K}^{+}$in (A) the odontophore retractor (traces above time base), (B) the radular retractor (traces below time base) and (C) the radular sac muscles of Busycon. In A and B the first trace is a control response to $25 \mathrm{mmoll}^{-1} \mathrm{~K}^{+}$, the second trace is the response to $\mathrm{K}^{+}$after $10 \mathrm{~min}$ of pretreatment with $10^{-5} \mathrm{moll}^{-1}$ BAYK 8644 and the third trace is the response $2 \mathrm{~h}$ after washout with sea water. In $\mathrm{C}$ the first trace is the control response to $25 \mathrm{mmol}^{-1} \mathrm{~K}^{+}$, the second trace is the response after $10 \mathrm{~min}$ of pretreatment with $10^{-8} \mathrm{moll}^{-1}$ BAY K 8644 , the third trace is the response after $10 \mathrm{~min}$ of pretreatment with $10^{-6} \mathrm{moll}^{-1}$ BAY K 8644 and the fourth trace is the response after $10 \mathrm{~min}$ of pretreatment with $10^{-5} \mathrm{moll}^{-1}$ BAY K 8644 . Note the fall in baseline tension on addition of BAYK 8644 . The fifth trace is the response after $2 \mathrm{~h}$ of washout with sea water. Time scale, major marks are $1 \mathrm{~min}$. 

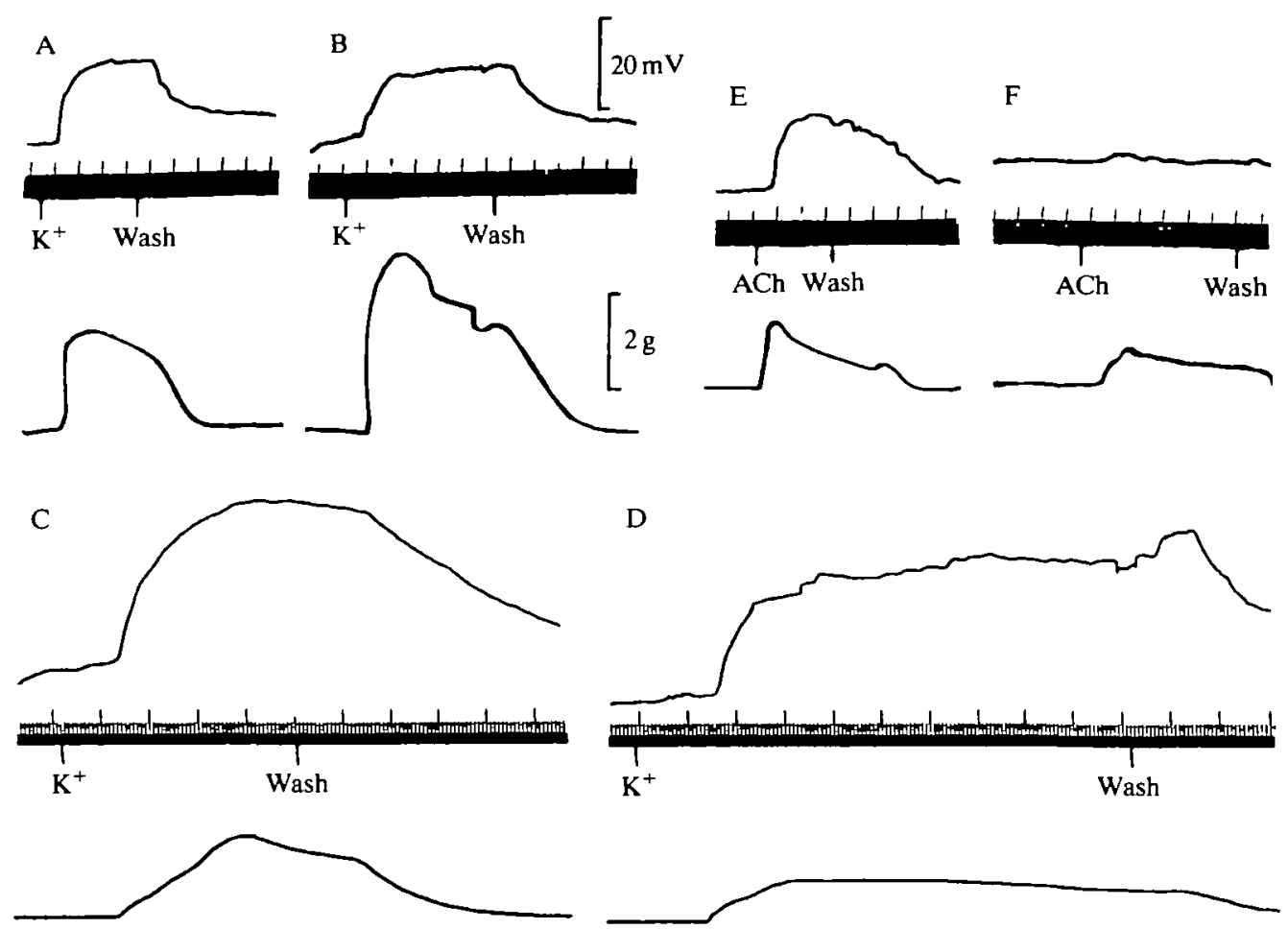

Fig. 2. Simultaneous sucrose-gap recordings of membrane potential (upper trace) and tension (lower trace) of the radular protractor muscle in response to depolarization. induced by $150 \mathrm{mmol}^{-1} \mathrm{~K}^{+}(\mathrm{A}-\mathrm{D})$ and $10^{-5} \mathrm{moll}^{-1}$ acetylcholine (E and $\mathrm{F}$ ) during BAY K 8644 perfusion. (A) Control responses to $\mathrm{K}^{+}$; (B) responses to $\mathrm{K}^{+}$after $10 \mathrm{~min}$ of perfusion with $10^{-7}$ moll $1^{-1}$ BAY K 8644; (C) control responses to $\mathrm{K}^{+}$of a different muscle; (D) responses to $\mathrm{K}^{+}$of this muscle after perfusion with $10^{-6} \mathrm{moll}^{-1}$ BAY K 8644 . Note the enhancement of tension with $10^{-7}$ moll ${ }^{-1}$ BAY K 8644 and the inhibition at $10^{-6} \mathrm{moll}^{-1}$, but without appreciable change in depolarization level. (E) Control tension and depolarization induced by $\mathrm{ACh} ;(\mathrm{F})$ responses to $\mathrm{ACh}$ after $10 \mathrm{~min}$ of perfusion with $10^{-7} \mathrm{moll}^{-1}$ BAY K 8644 . Note the inhibition of both ACh-induced depolarization and subsequent force development. First time base down-mark shows addition, second shows washout. Time scale, major marks are $1 \mathrm{~min}$. Tension and depolarization scales apply to all traces.

$\left(10^{-5} \mathrm{~mol}^{-1}\right)$ BAY K 8644 itself caused a small drop in resting tone in the muscle. Recovery of the response after this treatment was poor, with over $40 \%$ force inhibition $2 \mathrm{~h}$ after a washout in sea water (Fig. 1C).

In the radular protractor, the action of BAY K 8644 on the response to $150 \mathrm{mmoll}^{-1} \mathrm{~K}^{+}$was concentration-dependent, being excitatory at $10^{-7} \mathrm{moll}^{-1}$ but inhibitory at higher concentrations (Fig. 2). This was mirrored in the sucrosegap recordings which showed that the $\mathrm{K}^{+}$-induced depolarization was unaffected by $10^{-7} \mathrm{moll}^{-1}$ BAY K 8644 , but showed $25 \%$ inhibition at $10^{-6} \mathrm{moll}^{-1}$.

The response to $80 \mathrm{mmoll}^{-1} \mathrm{~K}^{+}$was also affected differently in different muscles by BAY K 8644 . In the odontophore retractor and the radular retractor 

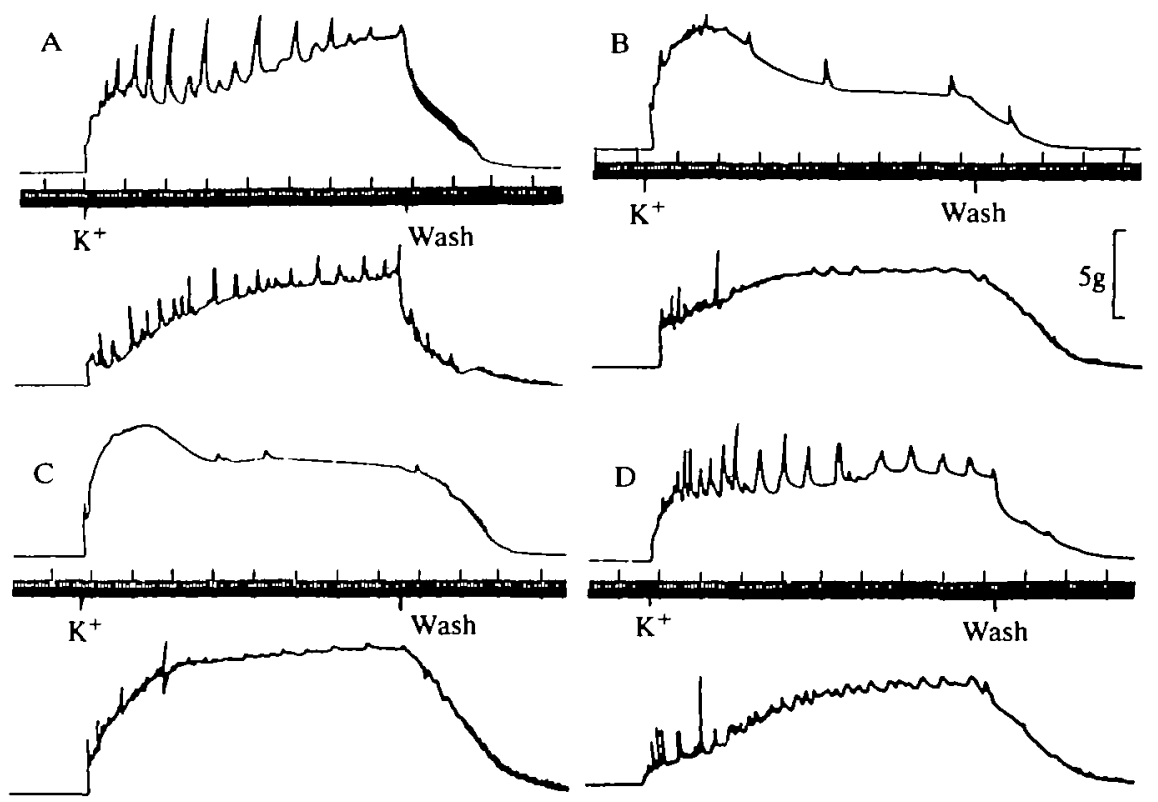

Fig. 3. The effect of BAY K 8644 on the contracture induced by $80 \mathrm{mmoll}^{-1} \mathrm{~K}^{+}$in the odontophore retractor muscle (trace above time base) and the radular retractor muscle (trace below time base). Treatments were as follows: (A) control responses to $80 \mathrm{mmol}^{-1} \mathrm{~K}^{+}$; (B) responses after $10 \mathrm{~min}$ of perfusion with $10^{-6} \mathrm{~mol}{ }^{-1}$ BAY K 8644 ; (C) responses after 10 min of perfusion with $10^{-5} \mathrm{moll}^{-1} \mathrm{BAY} \mathrm{K} 8644$; (D) recovery of response after $1 \mathrm{~h}$ of perfusion with sea water. Tension scale applies to all traces. First time base down-mark shows $\mathrm{K}^{+}$addition, second mark shows washout. Time base, major intervals are $1 \mathrm{~min}$.

muscles, fast twitch activity was greatly reduced by BAY K 8644 , but tonic force was slightly enhanced, not an effect expected from an agent acting upon slow calcium channels (Fig. 3). In contrast, the maintained tonic force in response to $80 \mathrm{mmoll}^{-1} \mathrm{~K}^{+}$of the radular sac muscle was inhibited in a dose-dependent manner, up to nearly $50 \%$ inhibition at $10^{-5} \mathrm{moll}^{-1}$ BAY K 8644 ; initial tonic force was slightly enhanced with $10^{-6} \mathrm{moll}^{-1}$ BAY K 8644 but was not maintained (Fig. 4). As with the other two muscles, fast twitch activity of the radular sac muscle was eliminated by BAYK 8644 . While the odontophore and radular retractors recovered well from BAY K 8644 treatment, the radular sac muscle remained greatly inhibited in both phasic and tonic components even $1 \mathrm{~h}$ after washout (Fig. 4).

BAYK 8644 consistently inhibited the response of all four muscles to $5 \times 10^{-6} \mathrm{~mol}^{-1} \mathrm{ACh}$. Sucrose-gap studies of the radular protractor muscle showed that BAYK 8644 at a concentration as low as $10^{-7}$ moll $^{-1}$ reduced both $\mathrm{ACh}$ induced depolarization and subsequent tonic force by over $60 \%$ (Fig. 2). The radular sac muscle was also strongly inhibited by BAY K 8644, the ACh-induced tonic force being reduced by $50 \%$ with $10^{-5} \mathrm{moll}^{-1}$ BAY K 8644 , and very poor 
recovery was seen even $1 \mathrm{~h}$ after washout with sea water (Fig. 5). In the odontophore retractor the ACh response was slightly inhibited by BAY K 8644 , while in the radular retractor muscle the maintained tonic force in the presence of $10^{-5} \mathrm{moll}^{-1}$ BAY K 8644 showed frequent transient relaxations. In all four muscles, tonic force was not well sustained in the presence of BAY K 8644 (Fig. 5).
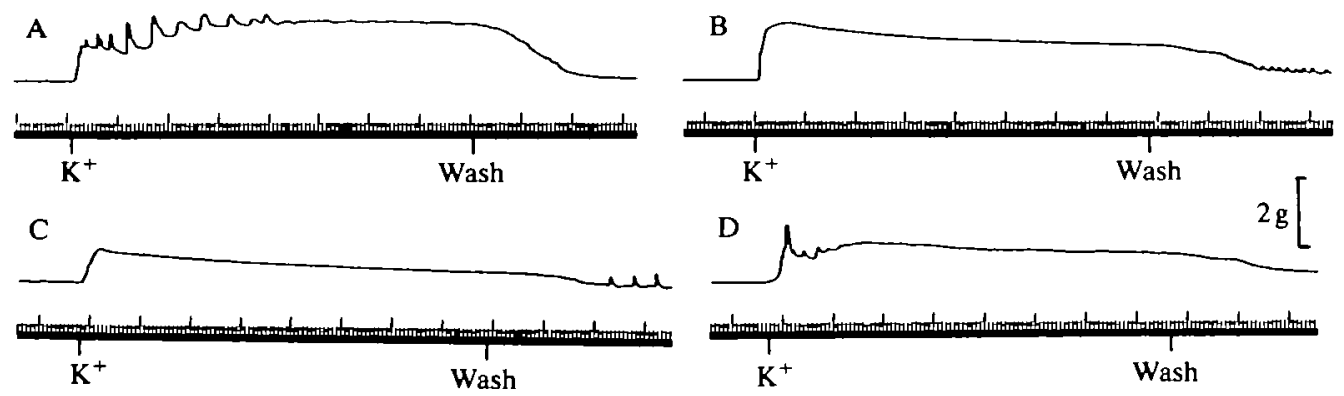

Fig. 4. The effect of BAY K 8644 on the response to $80 \mathrm{mmoll}^{-1} \mathrm{~K}^{+}$of the radular sac muscle. (A) Control response in normal sea water; (B) response after $10 \mathrm{~min}$ of perfusion with $10^{-6} \mathrm{moll}^{-1}$ BAY K 8644; (C) response after $10 \mathrm{~min}$ of perfusion with $10^{-5} \mathrm{moll}^{-1}$ BAYK 8644; (D) poor response recovery after $1 \mathrm{~h}$ of washout in sea water. Tension scale applies to all traces. First time base down-mark is $\mathrm{K}^{+}$addition, second is washout. Time scale, major intervals are $1 \mathrm{~min}$.
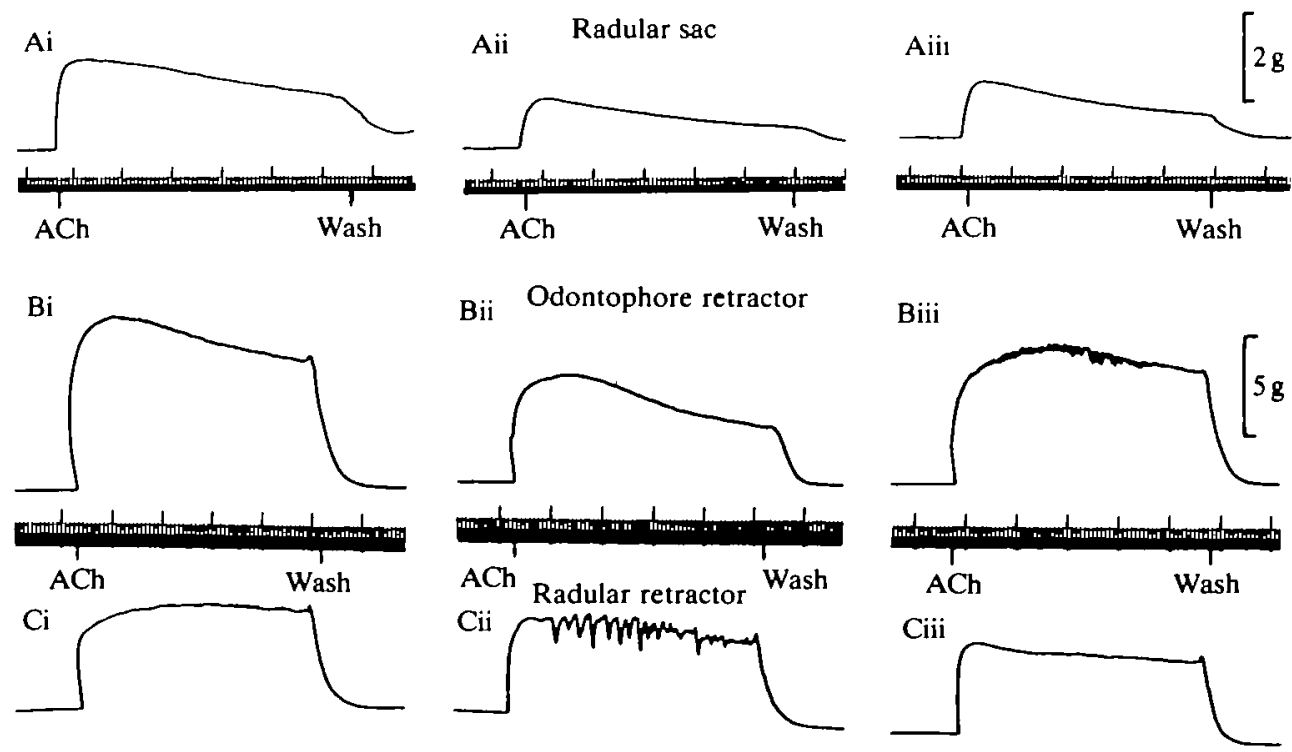

Fig. 5. The effect of BAY K 8644 on ACh-induced responses of (A) the radular sac, (B) the odontophore retractor and (C) the radular retractor muscles. In each case $\mathrm{i}$ is the control response to $5 \times 10^{-6} \mathrm{~mol}^{-1} \mathrm{ACh}$, ii is the response after $10 \mathrm{~min}$ of perfusion with $10^{-5} \mathrm{moll}^{-1}$ BAY K 8644 and iii is the response $1 \mathrm{~h}$ after washout of sea water. The $5 \mathrm{~g}$ tension scale applies to all traces in B and C. First time base down-mark is ACh addition, second is washout of sea water. Time base, major intervals are $1 \mathrm{~min}$. 


\section{The effects of Mytelase}

In these muscles BAYK 8644 was not selective enough to differentiate well between $\mathrm{K}^{+}$-induced and $\mathrm{ACh}$-induced membrane depolarization events. In the hope of selectively examining the $\mathrm{ACh}$ route leading to release of cellular calcium for contraction, we used Mytelase (ambenonium chloride), a potent selective antiacetylcholinesterase with prolonged stable action; it is not itself hydrolysed.

Mytelase enhanced the tonic force developed due to cumulative ACh-induced depolarization without altering receptor threshold (Fig. 6). However, at $10^{-4} \mathrm{moll}^{-1}$, Mytelase clearly enhanced the response to $10^{-5} \mathrm{moll}^{-1} \mathrm{ACh}$ but inhibited responses to higher doses of $\mathrm{ACh}$, suggesting receptor desensitization, a phenomenon not seen in control responses up to $10^{-4} \mathrm{moll}^{-1} \mathrm{ACh}$ in the absence of Mytelase (Fig. 6E). There is evidence that Mytelase may have anti-cholinoreceptor activity in the heart of Venus mercenaria (Luduena and Brown, 1952), which may also explain the sharp inhibition of responses to very high doses of $\mathrm{ACh}$ at high concentrations of Mytolon (Figs 6, 7B).

The three muscles were similar in ACh dose-response relationship, as shown in Fig. 7A for the radular sac muscle and the odontophore retractor muscle, and in Fig. 7B for the radular retractor muscle. The effect of Mytelase, shown in Fig. 7B for the radular retractor muscle, was similar in all the muscles.

\section{The effect of Mytolon}

To determine whether ACh-induced increases in cellular calcium level (Huddart and Hill, 1988) did indeed operate via the $\mathrm{ACh} /$ cholinoreceptor interaction, causing sodium-dependent depolarization (Hill and McDonald-Ordzie, 1979), we employed Mytolon (benzoquinonium chloride), a powerful anti-cholinoreceptor neuromuscular blocking drug. The effects of Mytolon on ACh dose-response relationships were examined in the odontophore retractor and radular retractor muscles. Mytolon not only shifted the threshold to higher ACh levels but, at $10^{-4} \mathrm{moll}^{-1}$, it also significantly reduced the maximum response to ACh by $55 \%$. Using the standard $\mathrm{pA}_{2}$ determination method, Mytolon was found to show competitive antagonism to the cholinoreceptors in the muscles. $\mathrm{A} \mathrm{pA}_{2}$ value of -6 was obtained, as to be expected if $\mathrm{ACh}$ were activating cellular calcium via cholinoreceptors. We used Mytolon to examine the relationship between AChand $\mathrm{K}^{+}$-operated pathways for the control of cellular calcium concentration (e.g. Fig. 8). The ACh dose-response curve for the radular retractor muscle in the presence of increasing concentrations of Mytolon shows the inhibitory action of this blocker (Fig. 9).

\section{ACh $/ \mathrm{K}^{+}$synergism}

The Mytelase experiments showed that anti-acetylcholinesterase action could enhance calcium release from the cellular pool normally accessed by $\mathrm{ACh}$. To test whether this calcium pool was also accessed by $\mathrm{K}^{+}$-induced depolarization or whether a separate $\mathrm{K}^{+}$-accessed calcium pool was present and was independent of 

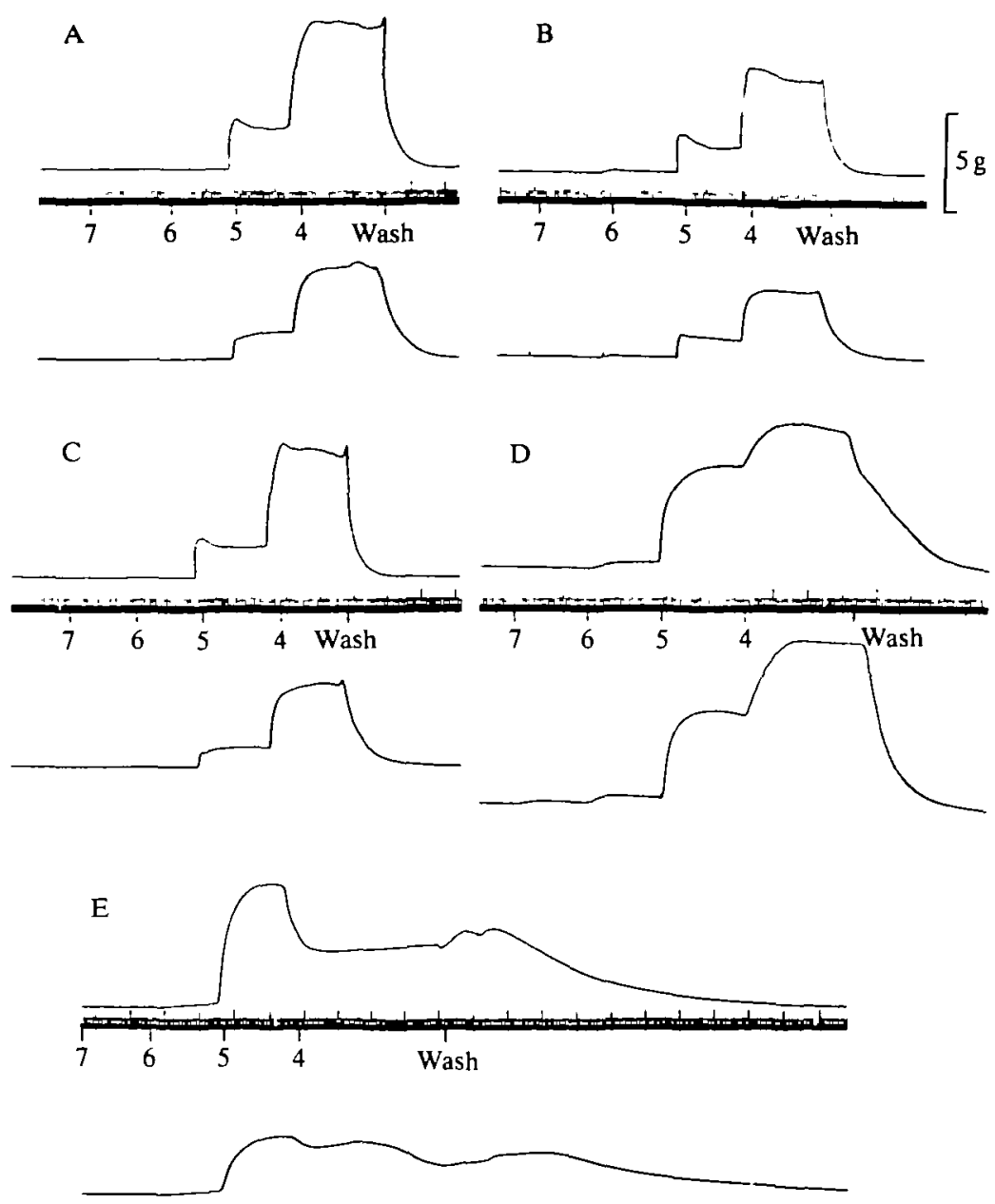

Fig. 6. The effect of Mytelase on the cumulative acetylcholine dose-response patterns of two different radular retractor muscle preparations. (A) Control dose-response patterns; (B) dose-response relationship after $10 \mathrm{~min}$ of pretreatment with $10^{-7} \mathrm{moll}^{-1}$ Mytelase; (C) response pattern after $10 \mathrm{~min}$ of pretreatment with $10^{-6} \mathrm{moll}^{-1}$ Mytelase; (D) response pattern after $10 \mathrm{~min}$ of pretreatment with $10^{-5} \mathrm{moll}^{-1}$ Mytelase; (E) response pattern after pretreatment with $10^{-4} \mathrm{moll}^{-1}$ Mytelase. In E note the enhancement of the response to $10^{-5} \mathrm{moll}^{-1} \mathrm{ACh}$, but the inhibition at higher $\mathrm{ACh}$ concentrations. Time scale, down-mark numbers represent $-\log [\mathrm{ACh}]$ (in $\mathrm{moll}^{-1}$ ); major time intervals are $1 \mathrm{~min}$. Tension scale applies to all traces.

ACh action, we exposed all three muscles to $80 \mathrm{mmoll}^{-1} \mathrm{~K}^{+}$and compared the responses with the response to $80 \mathrm{mmoll}^{-1} \mathrm{~K}^{+}$followed by $10^{-5} \mathrm{moll}^{-1} \mathrm{ACh}$, and then with the response to $\mathrm{ACh}$ followed by high- $\mathrm{K}^{+}$saline. Since these are concentrations of potassium and acetylcholine which induce on their own between 0 and $60 \%$ of maximal force, any synergistic effects would be noticeable. In none 

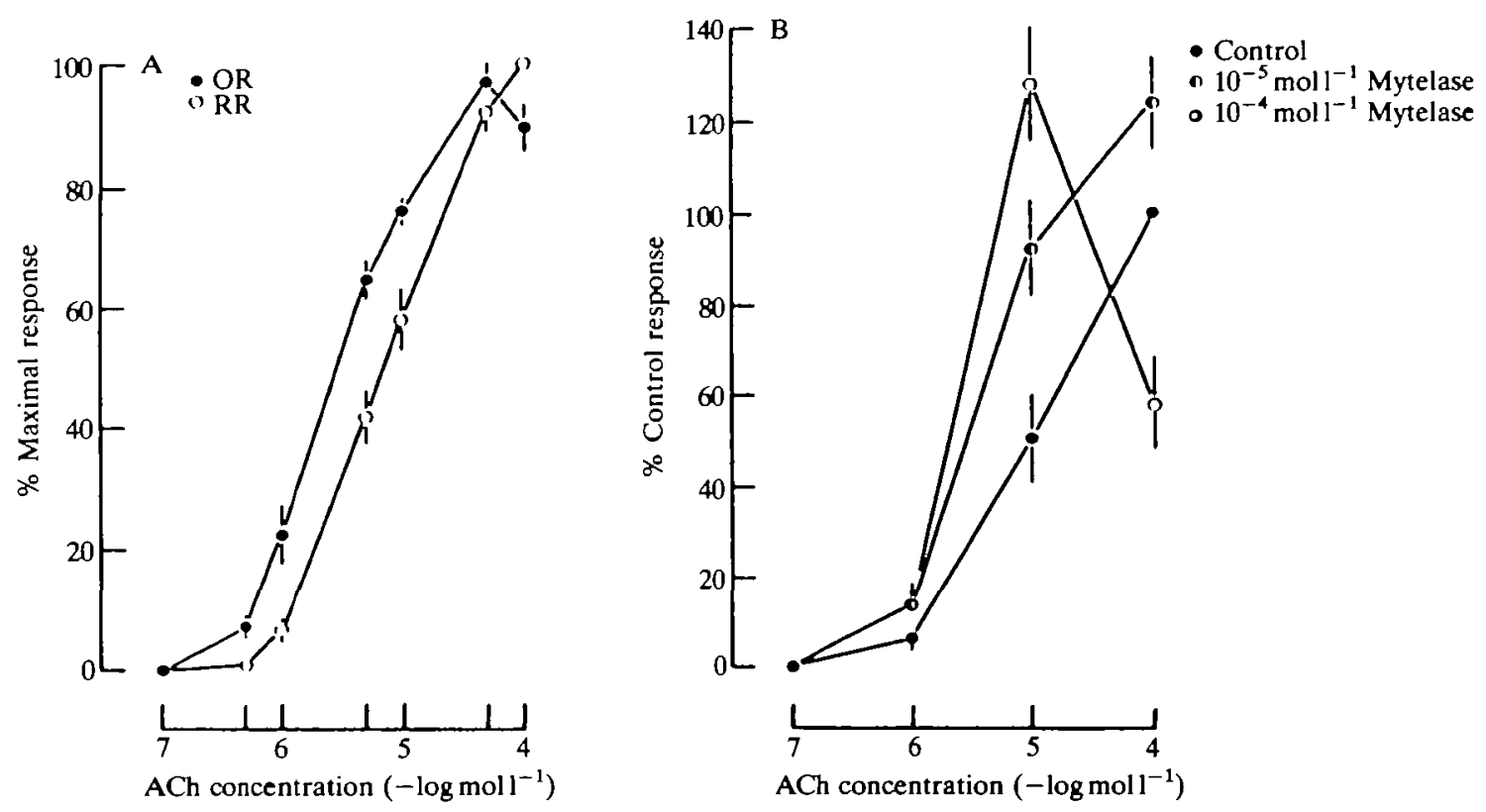

Fig. 7. (A) Acetylcholine dose-response curves for the odontophore retractor (OR, filled circles) and radular retractor muscle (RR, open circles). Each point is the mean of four responsests.E. of the mean. (B) The effect of Mytelase on the ACh dose-response curve of the radular retractor muscle. Note, with $10^{-4} \mathrm{moll}^{-1}$ Mytelase, the inhibition of the responses to ACh at doses above $10^{-5} \mathrm{moll}^{-1}$. Each point is the mean of four responses \pm S.E. of the mean.

of these experiments (e.g. Fig. 10) did we observe any synergism in the interaction of the two depolarization pathways.

\section{Discussion}

The buccal muscles of Busycon show an acute dependence upon extracellular calcium for contraction (Huddart and Hill, 1988; Huddart et al. 1990b) but contain a cellular pool of calcium, like other molluscan muscles. This pool needs continuous re-priming from the external medium. Such a pool has been shown in molluscs by oxalate and pyroantimonate calcium deposition studies (Heumann, 1969; Sugi and Atsumi, 1973; Atsumi et al. 1974; Suzuki and Sugi, 1978), by energy-dispersive X-ray microanalysis (Huddart et al. 1977) and by radiocalcium exchange (Hagiwara and Nagai, 1970; Tameyasu and Sugi, 1976). In several of these studies, cellular calcium translocation has been observed in muscles fixed during ACh-and $\mathrm{K}^{+}$-induced contracture and the consensus view is that at rest the calcium pool is peripherally located just below the plasma membrane whereas during mechanical activity it becomes diffusely distributed throughout the myoplasm (Heumann, 1969; Sugi and Atsumi, 1973; Huddart et al. 1977; Suzuki and Sugi, 1978). In addition, isolated submembrane vesicles have been showd 
A

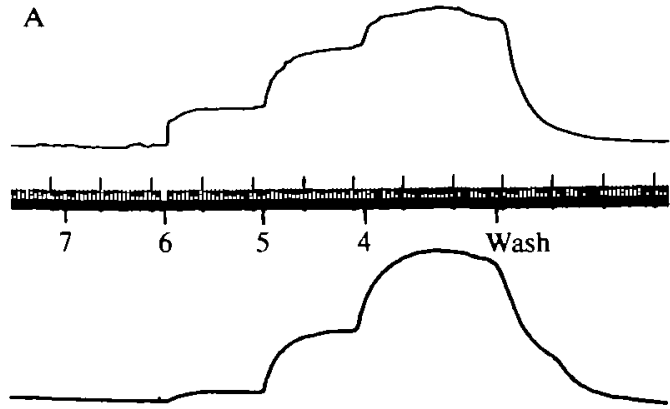

C

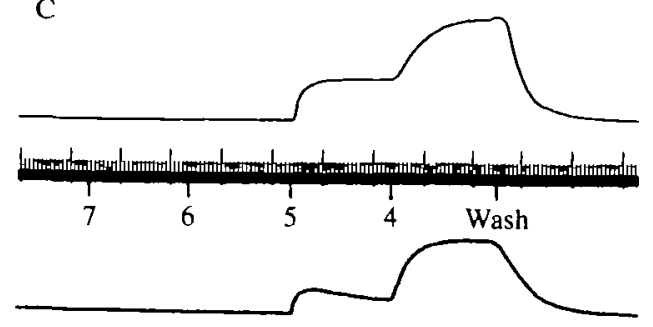

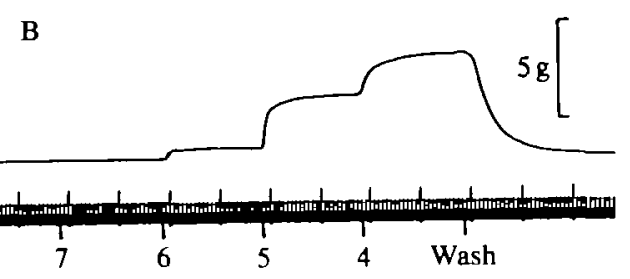

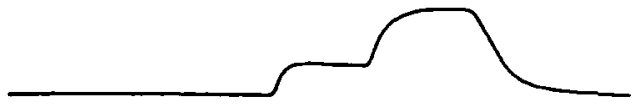

$\mathrm{D}$

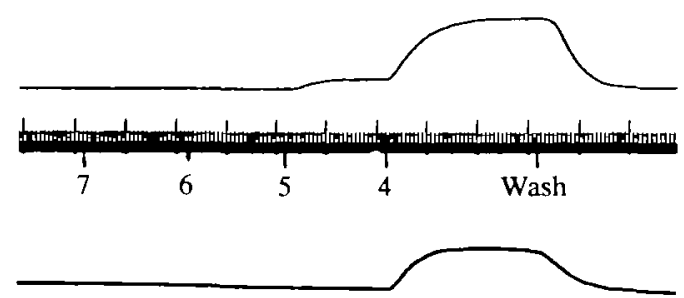

Fig. 8. The effect of Mytolon on the acetylcholine dose-response pattern in the odontophore retractor (trace above time base) and radular retractor muscles (trace below time base). Treatments were as follows: (A) control dose-response relationship in normal sea water; (B) dose-response relationship after 10 min of pretreatment with $10^{-7}$ moll $^{-1}$ Mytolon; (C) dose-response relationship after $10 \mathrm{~min}$ of pretreatment with $10^{-5} \mathrm{moll}^{-1}$ Mytolon; (D) dose-response relationship after $10 \mathrm{~min}$ of pretreatment with $10^{-4} \mathrm{moll}^{-1}$ Mytolon. Note the shift of the dose-response relationship to the right in the presence of Mytolon. Time base down-mark numbers are $-\log [\mathrm{ACh}]$ (in mol $\mathrm{l}^{-1}$ ) and major time intervals are $1 \mathrm{~min}$.

in vitro to be able to take up radiocalcium (Gogjian and Bloomquist, 1977; Huddart et al. 1977).

Submembrane vesicles are common in molluscan muscle (Dorsett and Roberts, 1980; Hunt, 1981) and the radular protractor of Busycon, the only proboscis muscle examined in this respect, also shows abundant submembrane vesicles (Sanger and Hill, 1972, 1973). These vesicles may form the loci of calcium exchange with the external medium and may also be the source of activator calcium for ACh-induced contractures as well as the point of calcium-induced release of calcium (CIRC) in $\mathrm{K}^{+}$-induced contractures (Sugi and Atsumi, 1973; Tameyasu and Sugi, 1976). In many excitation-contraction (EC) coupling systems $\mathrm{ACh}$ releases calcium from the sarcoplasmic reticulum (SR) either by generating secondary messengers or by voltage-mediated calcium release from the SR (Berridge, 1988). However, molluscan muscles do not possess the elaborate Tsystem and SR array of insect or vertebrate muscles. It is, however, possible that Ch may cause the release of calcium from the submembrane vesicle system seen 


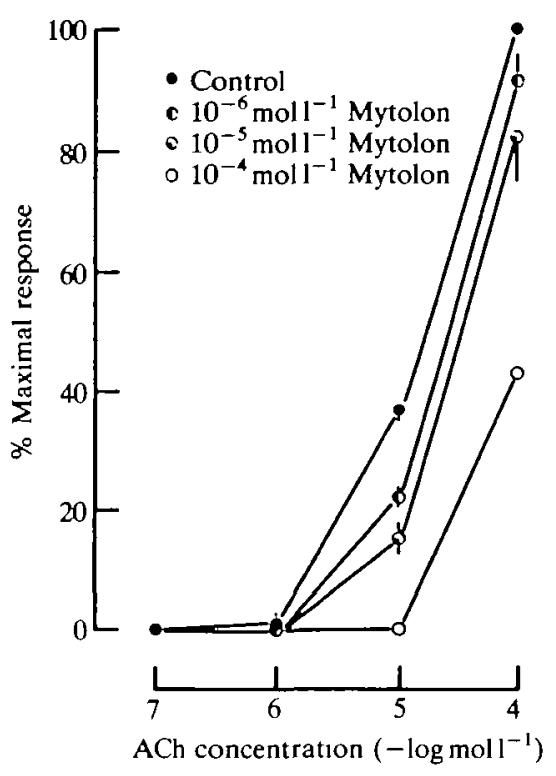

Fig. 9. The effect of Mytolon on the ACh dose-response curve of the radular retractor muscle. Note the inhibitory shift of the responses to acetylcholine to the right of control in the presence of Mytolon. Each point is the mean of four responses \pm s.E. of the mean.

in molluscan muscle by induction of a secondary messenger, whereas high- $\mathrm{K}^{+}$ saline may cause the release of calcium from the same vesicles by CIRC. While fine structural and radiocalcium studies establish the existence of a cellular calcium pool which is mobilized during $\mathrm{K}^{+}$-induced and ACh-induced contractures, they give no clue as to whether the pool has independent fractions mobilized separately by $\mathrm{ACh}$ and by high- $\mathrm{K}^{+}$saline.

Recently Reilly and Peretz (1987) observed in Aplysia gill efferent vein muscle that manganese ions abolished $\mathrm{ACh}$-induced contractures but only partly inhibited $\mathrm{K}^{+}$-induced contractures. In this muscle, nominally calcium-free media abolished the ACh-induced contracture and reduced the $\mathrm{K}^{+}$-induced contracture to $16 \%$ of control. Reilly and Peretz (1987) concluded that $\mathrm{ACh}$ and high- $\mathrm{K}^{+}$salines mobilized different cellular calcium stores to initiate EC coupling. Studies on the EC coupling mechanism of the anterior byssus retractor muscle (ABRM) of Mytilus had earlier suggested that $\mathrm{ACh}$-induced contractures were mediated by calcium from cellular stores while $\mathrm{K}^{+}$-induced contractures were mediated by calcium influx from the medium (Bloomquist and Curtis, 1975; Twarog, 1976; Sugi and Yamaguchi, 1976; Tameyasu and Sugi, 1976). There is evidence that AChinduced depolarization results from a receptor-operated ion channel inducing sodium influx (Wilkens and Greenberg, 1973) and that $\mathrm{K}^{+}$-induced depolarization induces calcium influx (Reilly and Peretz, 1987). Supporting this view is the observation of Tameyasu and Sugi (1976) that radiocalcium uptake was markedlf 

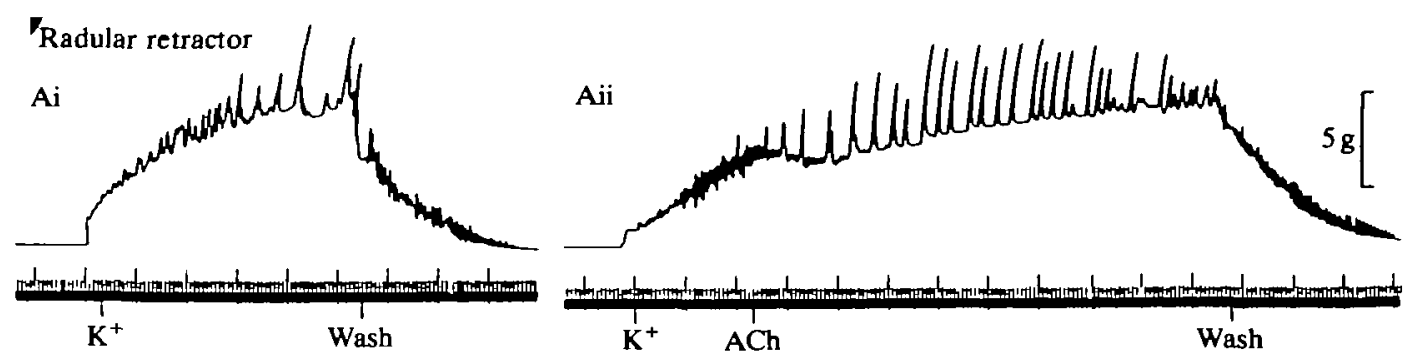

Odontophore retractor

$\mathrm{Bi}$

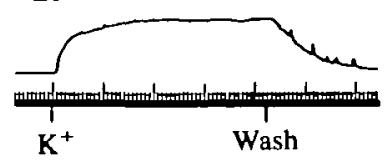

Radular sac

$\mathrm{Ci}$

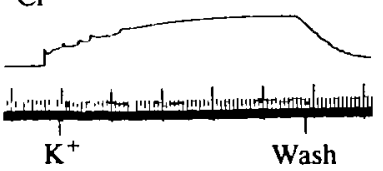

Bii

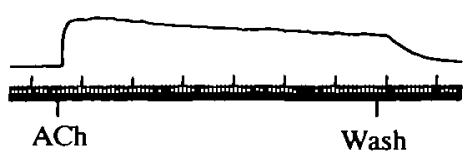

Cii

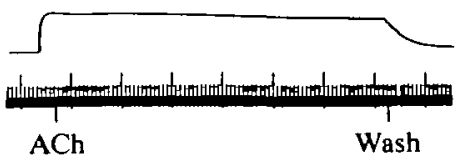

Biii

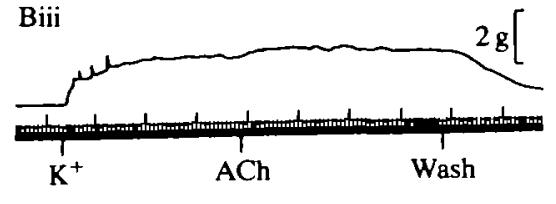

Ciii

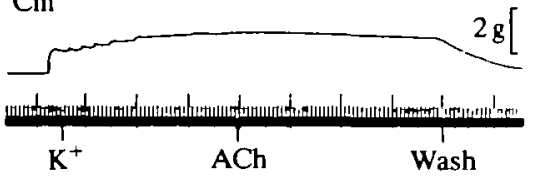

Fig. 10. The effect of $\mathrm{K}^{+}$and $\mathrm{ACh}$ application on tension generation in the radular retractor (A), the odontophore retractor $(\mathrm{B})$ and the radular sac $(\mathrm{C})$ muscles of Busycon. (Ai) Control response to $80 \mathrm{mmoll}^{-1} \mathrm{~K}^{+}$; (Aii) response to $80 \mathrm{mmoll}^{-1} \mathrm{~K}^{+}$ and the subsequent addition of $10^{-5} \mathrm{moll}^{-1} \mathrm{ACh}$. (Bi) Control response to $80 \mathrm{mmoll}^{-1}$ $\mathrm{K}^{+}$; (Bii) response to $10^{-5} \mathrm{moll}^{-1} \mathrm{ACh}$; (Biii) combined response. (Ci) Response to $80 \mathrm{mmoll}^{-1} \mathrm{~K}^{+}$; (Cii) response to $10^{-5} \mathrm{moll}^{-1} \mathrm{ACh}$; (Cii) combined response. Note the lack of synergism between $\mathrm{K}^{+}$and $\mathrm{ACh}$. Time scale, major marks are 1 min.

increased by high- $\mathrm{K}^{+}$solutions while salines containing $\mathrm{ACh}$ did not significantly increase radiocalcium uptake in Mytilus ABRM.

Our experiments here were designed to answer two questions. First, are there two separate mechanisms for initiating the rise in cellular calcium level needed for $\mathrm{EC}$ coupling, one mechanism operated by $\mathrm{ACh}$-induced depolarization, the other by $\mathrm{K}^{+}$-induced depolarization? Second, are there two separate cellular calcium pools which can be independently mobilized by $\mathrm{ACh}$ on the one hand and high- $\mathrm{K}^{+}$ salines on the other?

All four proboscis muscles of Busycon differ from the ABRM and Aplysia gill vein muscle in that both $\mathrm{ACh}$-induced and $\mathrm{K}^{+}$-induced contractures are eliminated in calcium-free sea water (Huddart and Hill, 1988; Huddart et al. 1990b), but the depolarizations induced by these agonists persist in calcium-free conditions. Furthermore Hill and Licis (1985) showed that lanthanum blocked the responses to both $\mathrm{K}^{+}$and $\mathrm{ACh}$ in Busycon radular protractor muscle, in clear contrast to the findings of Reilly and Peretz (1987).

As suggested by Reilly and Peretz (1987), $\mathrm{K}^{+}$-induced depolarization leads to calcium entry while ACh-induced depolarization (by sodium entry) leads to mtracellular calcium release. We expected BAY K 8644 to augment $\mathrm{K}^{+}$-induced 
responses and be without effect on ACh-induced responses. Although BAY K 8644 did consistently inhibit responses to ACh it exerted a variety of effects on responses to $\mathrm{K}^{+}$. A surprising finding was that BAY K 8644 consistently eliminated the fast twitches of the $80 \mathrm{mmol}^{-1} \mathrm{~K}^{+}$response in a manner similar to inactivation of fast twitches in these muscles by cumulative $\mathrm{K}^{+}$depolarization (Huddart et al. 1990a).

We did not expect BAY K 8644 to affect fast twitch activity directly, but the enhancement of tonic force induced by $80 \mathrm{mmol}^{-1} \mathrm{~K}^{+}$seen here with this agent suggests that two types of calcium channel might be coupled in this muscle. That is, the mechanism enhancing tonic force may inactivate fast channel activity without further depolarization. It is difficult to determine where BAY K 8644 acts. Its only consistent action in all four muscles was inhibition of responses to $\mathrm{ACh}$; hence it may selectively affect some part of the ACh-induced depolarization pathway for cellular calcium release. Our sucrose-gap studies showed that BAY K 8644 not only inhibited $\mathrm{ACh}$-induced contractures but also inhibited the ACh-induced depolarization which initiates them. Since ACh-induced depolarization is an event associated with sodium influx, BAY K 8644 may have inhibited membrane sodium influx, and thus have secondarily reduced calcium mobilization from the cellular calcium pool.

It is unlikely that BAY K 8644 entered the muscle fibres to affect the cellular calcium pool directly since it would then have similar effects on both $\mathrm{K}^{+}$- and ACh-induced responses. Possibly BAY K 8644 may have inhibited ACh-operated sodium-gating ion channels of the muscle fibres. Although molluscs seem to possess fast and slow types of calcium channel, they are not pharmacologically separable with BAYK 8644 as they are in mammals. In our experiments, $\mathrm{K}^{+}$. induced depolarization probably caused a steady influx of calcium. The time course over which this occurs (from seconds to minutes) will depend upon the driving force for calcium influx. This may account for the differences in the rate of force development seen with different levels of external potassium, reflecting differences in the rate of activation of CIRC (see Berridge and Galione, 1988).

Since BAY K 8644 failed to separate the $\mathrm{K}^{+}$and ACh pathways that initiate EC coupling, we tried to isolate these with Mytelase and Mytolon, with more success. Mytolon inhibited ACh-induced force, showing that ACh acted only to release cell calcium through its receptor-operated sodium channel. Mytelase enhanced AChinduced responses, without affecting receptor threshold, and at high concentrations it led to symptoms of either receptor desensitization or direct cholinoreceptor antagonism (Fig. 6). However, these experiments did not tell us whether the two separate pathways released cellular calcium from a common pool or from two separate pools. To test this we used $\mathrm{ACh} / \mathrm{high}-\mathrm{K}^{+}$synergism experiments.

Sequential exposure of muscles to $\mathrm{ACh}$ and high- $\mathrm{K}^{+}$saline did not lead in any case to enhanced force development. The non-additive effect of these agonists indicated that they did not operate on two separate calcium pools but merely released, by different mechanisms, calcium from a single common pool. 
It is most unlikely that $\mathrm{ACh}$ - and $\mathrm{K}^{+}$-induced depolarization operate via cyclic AMP and cyclic GMP as separate secondary messenger systems, since Ishikawa et al. (1981) have shown that neither ACh nor high- $\mathrm{K}^{+}$saline causes any changes in cyclic AMP and cyclic GMP levels in the ABRM.

The data we have on Busycon proboscis muscles do not support the hypothesis that $\mathrm{ACh}$ and high- $\mathrm{K}^{+}$saline induce the release of cellular calcium for EC coupling from two separate calcium pools. However, $\mathrm{ACh}$ and high- $\mathrm{K}^{+}$saline do release cellular calcium with differing efficiencies. Maximal ACh-induced contracture is achieved at far lower levels of membrane depolarization than are required for maximal $\mathrm{K}^{+}$-induced contractures (Reilly and Peretz, 1987; Huddart and Hill, 1988 ), indicating that the in vivo agonist is more efficient at triggering EC coupling than is depolarization induced by high- $\mathrm{K}^{+}$saline.

$\mathrm{HH}$ is most grateful to the Royal Society and the Wellcome Trust, DDB to the Wellcome Trust and RL to the Natural Environment Research Council for grants to support this work. This study was carried out while RL was in receipt of an NERC Research Studentship (GT4/85/ALS/20).

\section{References}

Atsumi, S., Sugi, H. and Aikawa, M. (1974). The role of calcium ions in the regulation of active and catch contractions in the anterior byssus retractor muscle of Mytilus edulis. Proc. Japan Acad. 50, 775-778.

Berridge, M. J. (1988). Inositol lipids and calcium signalling. Proc. R. Soc. B 234, 359-378.

Berridge, M. J. and Galjone, A. (1988). Cytosolic calcium oscillators. J. Fed. Am. Soc. exp. Biol. 2, 3074-3082.

Bloomquist, E. ANd Curtis, B. A. (1975). Net calcium fluxes in anterior byssus retractor muscle with phasic and catch contraction. Am. J. Physiol. 229, 1244-1248.

Dorsett, D. A. AND RoberTs, J. B. (1980). A transverse tubular system and neuromuscular junctions in a molluscan unstriated muscle. Cell Tissue Res. 206, 251-260.

Finet, M., Godfraind, T. and N-Khoury, G. (1985). The positive inotropic action of the nifedipine analogue BAY K 8644 in guinea pig and rat isolated cardiac preparations. $B r . J$. Pharmac. 86, 27-32.

Gogjlan, M. A. And Bloomquist, E. (1977). Calcium uptake by a subcellular membrane fraction of anterior byssus retractor muscle. Comp. Biochem. Physiol. 58C, 97-102.

Gopalakrishnan, V., Park, L. E. and Triggle, C. R. (1985). The effect of the calcium channel agonist BAY K 8644 on human vascular smooth muscle. Eur. J. Pharmac. 113, 447-451.

Hagiwara, E. AND NAGaI, T. (1970). ${ }^{45} \mathrm{Ca}$ movements at rest and during potassium contracture in Mytilus ABRM. Jap. J. Physiol. 20, 72-83.

HeumanN, H.-G. (1969). Calciumakkumulierende Strukturen in einem glatten Wirbellosenmuskel. Protoplasma 67, 111-115.

Hitl, R. B. (1958). The effects of certain neurohumors and other drugs on the ventricle and radular protractor of Busycon canaliculatum and on the ventricle of Strombus gigas. Biol. Bull. mar. biol. Lab., Woods Hole 155, 471-482.

Hill, R. B., Greenberg, R. J., Irisawa, H. and Nomura, H. (1970). Electromechanical coupling in a molluscan muscle, the radula protractor of Busycon canaliculatum. J. exp. Zool. 174, 331-348.

HiL, R. B. ANd LiCIS, P. (1981). Effect of neurohumors during shutdown of electrogenic sodium pumping in a molluscan muscle. Acta. physiol. scand. 22, 339-359.

HiLl, R. B. AND Licis, P. (1985). Lanthanum and caffeine affect both membrane responses and force in a molluscan muscle, the radular protractor of Busycon canaliculatum. Comp. Biochem. Physiol. 82C, 363-376. 
Hill, R. B. And McDonald-Ordzie, P. E. (1979). Ionic dependence of the response to acetylcholine of a molluscan buccal muscle; the radular protractor of Busycon canaliculatum. Comp. Biochem. Physiol. 62C, 19-30.

Huddart, H., Brooks, D. D., Hill, R. B. And Lennard, R. (1990a). Diversity of mechanical responses and their possible underlying mechanisms in the proboscis muscles of Busycon canaliculatum. J. comp. Physiol. B (in press).

Huddart, H., Brooks, D. D., Lennard, R. and Hill, R. B. (1990b). Unusual responses of proboscis muscles of Busycon canaliculatum to some calcium antagonist agents. J. comp. Physiol. B (in press).

Huddart, H. AND HiLl, R. B. (1988). Electromechanical uncoupling in a molluscan muscle examined by the sucrose gap technique. The effect of calcium antagonist and agonist agents. J. comp. Physiol. B 158, 501-512.

Huddart, H., Hunt, S. and Oates, K. (1977). Calcium movements during contraction in molluscan smooth muscle, and the loci of calcium binding and release. J. exp. Biol. 68, 45-56.

HuNT, S. (1981). Molluscan visceral muscle fine structure. General structure and sarcolemmal organization in the smooth muscle of the intestinal wall of Buccinum undatum. Tissue \& Cell 13, 283-297.

Ishikawa, T., Murakami, H. and Iwayama, Y. (1981). Changes in cAMP and cGMP levels induced by relaxing drugs in acetylcholine and potassium-treated molluscan smooth muscle. Comp. Biochem. Physiol. 70C, 171-176.

Kanmura, Y., Itoh, T. and Kuriyama, H. (1984). Agonist actions of BAYK 8644 , a dihydropyridine derivative, on the voltage-dependent calcium influx in smooth muscle cells of the rabbit mesenteric artery. J. Pharmac. exp. Ther. 231, 717-723.

LANGTON, P. D. AND Huddart, H. (1988). Voltage and time dependency of calcium mediated phasic and tonic responses in rat vas deferens smooth muscle - the effect of some calcium agonist and antagonist agents. Gen. Pharmac. 19, 775-787.

Luduena, F. P. AND Brown, T. G. (1952). Mytolon and related compounds as antagonists of acetylcholine on the heart of Venus mercenaria. J. Pharmac. exp. Ther. 105, 232-239.

MikKeLSEN, E. (1985). Comparison of effects of a new dihydropyridine, BAYK 8644, and nifedipine on spontaneous mechanical activity in rat portal vein. Br. J. Pharmac. 85, 383-385.

Reilly, W. M. ANd Peretz, B. (1987). Excitation-contraction coupling in non-spiking smooth muscle in the gill of Aplysia. J. comp. Physiol. B 157, 659-666.

SANGer, J. V. AND HiLL, R. B. (1972). Ultrastructure of the radula protractor of Busycon canaliculatum. Z. Zellforsch. mikrosk. Anat. 127, 314-321.

SANGER, J. W. AND HILL, R. B. (1973). The contractile apparatus of the radula protractor muscle of Busycon canaliculatum. Proc. malacol. Soc. Lond. 40, 335-341.

Sugi, H. AND ATsUmi, S. (1973). Localization of calcium accumulating structures in the anterior byssus retractor muscle of Mytilus edulis and their role in excitation-contraction coupling. Proc. Japan Acad. 49, 638-642.

Sugi, H. AND Yamaguchi, T. (1976). Activation of the contraction mechanisms in Mytilus smooth muscle. J. Physiol., Lond. 257, 531-547.

SuzuKI, S. AND Sugi, H. (1978). Ultrastructural and physiological studies on the longitudinal body wall muscle of Dolabella auricularia. II. Localization of intracellular calcium and its translocation during mechanical activity. J. Cell Biol. 79, 467-478.

TAMEYASU, T. AND Sugi, H. (1976). Effect of acetylcholine and high external potassium ions on ${ }^{45} \mathrm{Ca}$ movements in molluscan smooth muscle. Comp. Biochem. Physiol. 53C, 101-103.

Twarog, B. (1976). Aspects of smooth muscle function in molluscan catch muscle. Physiol. Rev. 56, 829-838.

WiLKENS, L. A. AND GREenberG, J. (1973). Effects of acetylcholine and 5-hydroxytryptamine and their ionic mechanisms of action on the electrical and mechanical activity of molluscan heart smooth muscle. Comp. Biochem. Physiol. 45A, 637-651. 